\title{
The environmental services of Pangarengan mangrove forest in Cirebon, Indonesia: conserving biodiversity and storing carbon
}

\author{
RIS HADI PURWANTO ${ }^{1}$, BUDI MULYANA ${ }^{1, \boldsymbol{\nu}}$, PUSPITA INTAN SARI ${ }^{1}$, MUHAMAD FAQIH HIDAYATULLAH $^{2}$, \\ AFNI ATIKA MARPAUNG ${ }^{3}$, ILHAM SATRIA RADITYA PUTRA ${ }^{4}$, AGIK DWIKA PUTRA \\ ${ }^{1}$ Department of Forest Management, Faculty of Forestry, Universitas Gadjah Mada. Jl. Agro No. 1, Bulaksumur, Sleman 55281, Yogyakarta, Indonesia. \\ Tel./fax.: +62-274-548815, `email: budimulyana@ugm.ac.id \\ ${ }^{2}$ Graduate Program in Remote Sensing, Faculty of Geography, Universitas Gadjah Mada. Jl. Sekip Utara, Sleman 55281, Yogyakarta, Indonesia \\ ${ }^{3}$ Graduate Program in Biology, Faculty of Biology, Universitas Gadjah Mada. Jl. Teknika Selatan, Sleman 55281, Yogyakarta, Indonesia \\ ${ }^{4}$ PT Cirebon Electric Power. Jl. Raya Cirebon-Tegal Km 8,5, Kanci Kulon, Astanajapura, Cirebon 45181, West Java, Indonesia
}

Manuscript received: 30 September 2021. Revision accepted: 28 November 2021

\begin{abstract}
Purwanto RH, Mulyana B, Sari PI, Hidayatullah MF, Marpaung AA, Putra ISR, Putra AD. 2021. The environmental services of Pangarengan mangrove forest in Cirebon, Indonesia: conserving biodiversity and storing carbon. Biodiversitas 22: $5609-5616$. Pangarengan mangrove forest in Cirebon, Indonesia, plays a vital role in providing ecosystem services, such as conserving biodiversity and storing carbon. The area of the Pangarengan mangrove forest is relatively small, but it is home to diverse flora and fauna. Also, it can mitigate climate change by storing carbon. Unfortunately, no specific records exist on biodiversity and carbon stock in the Pangarengan mangrove forest. This study aimed to record the diversity of flora and fauna of the Pangarengan mangrove using a survey approach and to estimate its carbon stocks using a non-destructive sampling method, except for seedlings, on 78 sampling plots, distributed randomly along the banks of the Cipaluh River. The results revealed that the flora consisted of 24 species, and the fauna was composed of 12 species. The mangrove species in the Pangarengan mangrove forest was dominated by Rhizophora mucronata. The carbon stocks varied among species or the life stages of plants (seedlings, saplings, poles, and trees). The carbon stock of Avicennia marina trees was the highest $(110.810 \mathrm{MgC} / \mathrm{ha})$, and the lowest was the seedlings of the Avicennia alba (0.005 MgC/ha). Furthermore, the interpretation of the images showed that the Pangarengan mangrove forest area is 21.5 ha. The mangrove forest is located in the coastal area of the Java Sea, $2.4 \mathrm{~km}$ from the residential area of Pangarengan village. It is crucial to preserve the Pangarengan mangrove forest because it functions as a source of biodiversity and carbon storage.
\end{abstract}

Keywords: Carbon accounting, climate change, essential ecosystem, species composition

\section{INTRODUCTION}

Mangrove forest provides environmental services for coastal areas, including conservation of biotas (fish, plankton, and benthos) in the mangrove waters (Sihombing et al. 2017), prevention of abrasion (Nordhaus et al. 2019; Sadono et al. 2020), provision of ecotourism destination (Pin et al. 2021), sequestration and storage of carbon in the belowground and aboveground (Widyastuti et al. 2018, Kusumaningtyas et al. 2019, Matatula et al. 2021), provision of medicinal plants (Arbiastutie et al. 2021), and mitigation of the effects of a tsunami (Husrin et al. 2012; Onrizal and Mansor 2016). Furthermore, preserving mangroves in Indonesia will be an effective strategy to mitigate climate change due to their ability to store the carbon above and below ground (Murdiyarso et al. 2015) and to prevent the mangrove conversion into other land uses (Eddy et al. 2017). Mangrove forest conversion resulted in $\mathrm{CO}_{2}$ emission greater than sequestration (Eddy et al. 2021).

Mangrove forests along the northern coasts of West Java have been converted into fish ponds, salt ponds, and other uses. According to data from Dinas Kehutanan Provinsi Jawa Barat (2018), the total mangrove forest in West Java was around 45,704.73 ha. Of these, 45,494.73 ha were located along the northern coastal area and 210.00 ha in the southern coastal region. Furthermore, Dinas Kehutanan Provinsi Jawa Barat (2018) stated that the mangrove forest in the Cirebon District was the smallest $(1,780 \mathrm{ha})$ along the northern coast of West Java. Mangroves in other sites along the northern coast of West Java, such as the Karawang District, have also been significantly degraded because they have been converted into fish ponds (Nusantara et al. 2015). Mangrove degradation occurs not only along the northern coast of West Java, but also in Central Java due to aquaculture, salt pond conversion, timber logging, land reclamation, and soil sedimentation (Setyawan and Winarno 2006).

Mangrove rehabilitation programs in the coastal areas of the Cirebon District require serious attention. Raharjo et al. (2016) reported that the mangrove forests in many Cirebon coastal areas continued to decrease from 20032014. Furthermore, Raharjo et al. (2016) recommended that the mangrove forest in the sub-districts of Mundu, Pangenan, and Astanajupara be rehabilitated, and the mangrove area in the Pangarengan village be protected. The Pangarengan village has $4.931 \mathrm{~km}$ of shoreline and $4.731 \mathrm{~km}$ of green belt composed of mangrove forest. Moreover, (Raharjo et al. 2016) also reported that the biodiversity in the sub-districts of the Mundu, Pangenan, 
and Pangarengan villages was significant and should be preserved.

Preserving the Pangarengan mangrove forest is vital for biodiversity and carbon stock preservation. Having a high biodiversity and carbon stock, the Pangarengan mangrove forest which is currently not a conservation area, needs to be proposed as an essential ecosystem because the existing conservation area has not been sufficient to protect all the species in the coastal areas. However, it is quite effective in reducing the rate of habitat destruction compared to unprotected areas (Geldmann et al. 2013). Moreover, preserving biodiversity and increasing the carbon stock can be achieved in the same places. Wirabuana et al. (2021) reported that species diversity affected the carbon stocks in the community forest. This study aimed to describe the biodiversity and estimate the carbon stock in the Pangarengan mangrove forest.

\section{MATERIALS AND METHODS}

\section{Research area}

The Pangarengan mangrove forest is located in a coastal area of the Java Sea in Pangarengan village, Cirebon district, West Java, Indonesia. The position of the Pangarengan mangrove forest is $6^{\circ} 45^{\prime} 35^{\prime}$ ' to $6^{\circ} 47^{\prime} 00^{\prime}$ ' $\mathrm{S}$ and $108^{\circ} 38^{\prime} 10^{\prime \prime}$ and $108^{\circ} 39^{\prime} 05^{\prime \prime}$ E (Figure 1). The mangrove forest is located in an estuary affected by freshwater from the Cipaluh River and seawater from the tide of the Java Sea. The 21.5 ha mangrove forest is $2.4 \mathrm{~km}$ from the residential area of Pengarengan village to the coast of the Java Sea.

\section{Data collection}

Fieldwork was conducted in June 2021. Data on biomass and carbon were collected using a sampling plot distributed using random sampling to represent the species composition for each zone. The mangrove zones perpendicular to the sea are proximal, medial, and distal, in which the vegetation composition is commonly different at each site ( Candri et al. 2020; Kusumaningtyas et al. 2019; Poedjirahajoe et al. 2017). The sampling used nested plots, in which the sub-plot sizes were $2 \times 2 \mathrm{~m}$ for seedlings, $5 \mathrm{x}$ 5 for saplings, and $10 \times 10 \mathrm{~m}$ for poles, while the plot size for trees was 20 × $20 \mathrm{~m}$ (Badan Standarisasi Nasional, 2011). Trees were woody plants with a diameter at breast height $(\mathrm{dbh})$ of $>20 \mathrm{~cm}$, poles with $\mathrm{dbh}$ of $10-20 \mathrm{~cm}$, saplings with a dbh of $2-10 \mathrm{~cm}$, and seedlings with dbh of $<2 \mathrm{~cm}$ and height of $1.5 \mathrm{~m}$. The nested sampling has also been used to estimate carbon stock and carbon sequestration in the mangrove forest in Indonesia (Nurmalahayati et al. 2020; Zulhalifah et al. 2021). In total, there were 78 sampling plots located on both banks of the Cipaluh River. The name, dbh, and height (total and bole height) of trees, poles, and saplings in the plots were recorded. The names of seedlings were recorded, then the seedlings were cut, put in the bags, dried in the oven for 48 hours at $85^{\circ} \mathrm{C}$ and weighed.
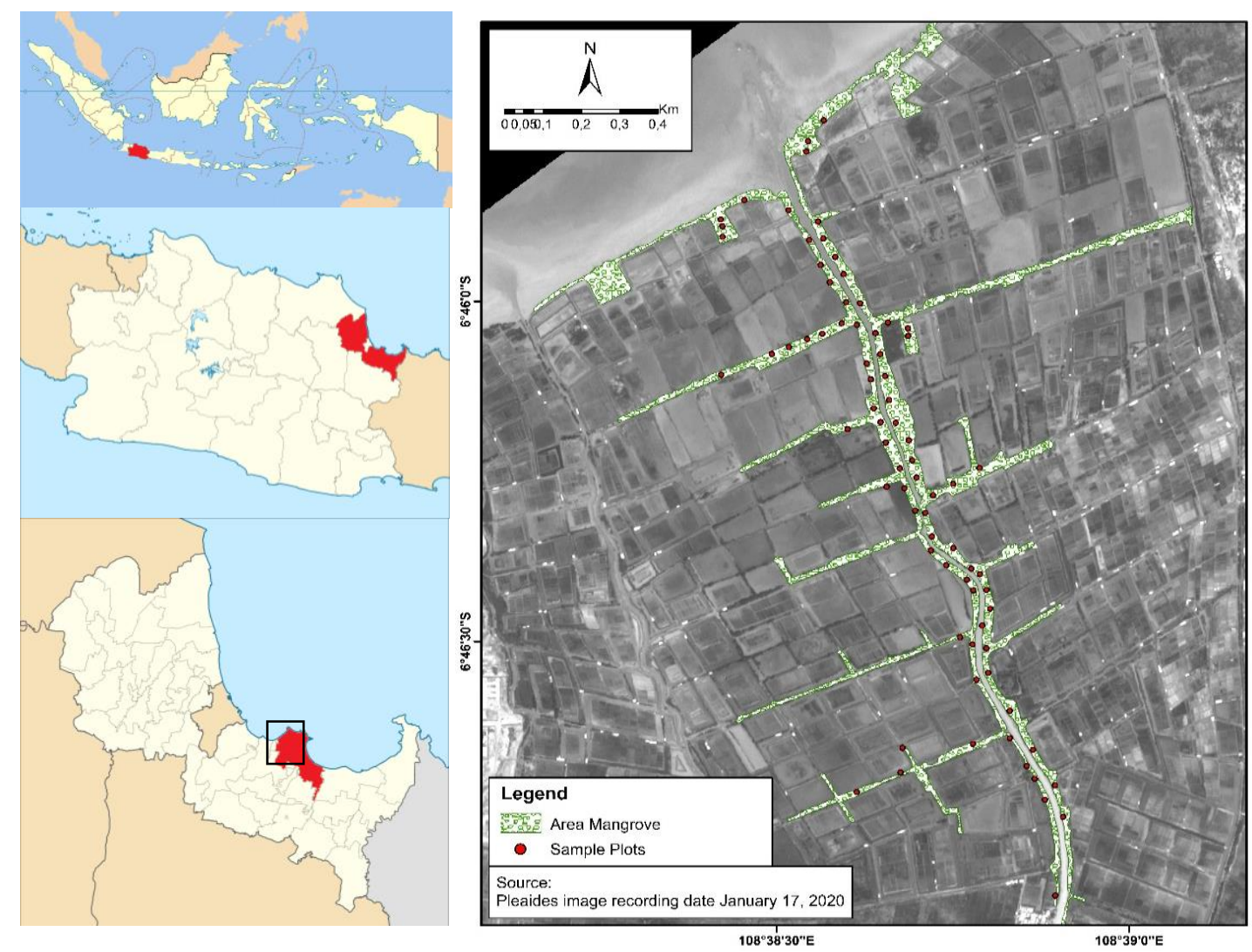

Figure 1. Research area of the Pangarengan mangrove forest, Cirebon District, Indonesia 
The flora and fauna data were collected using a survey method in the mangrove forest and pond areas. The fauna was documented using a digital single-lens reflex (DSLR) camera, and the coordinates were recorded. The flora was also documented using a DSLR camera, and then they were preserved and identified as herbaria (Irawan et al. 2021; Setyawan et al. 2005).

\section{Data analysis}

The data were analyzed quantitatively for carbon stocks and descriptively for biodiversity. The biomass estimate for saplings, poles, and trees was calculated using allometric equations (Table 1). For seedlings, the estimate of biomass in the plot level was the average dry mass of the seedling multiplied by the number of seedlings per plot (Kauffman and Donato 2012). The biomass was multiplied by 0.47 as the percentage of carbon content (Badan Standarisasi Nasional, 2011).

Following the standard set by Badan Standarisasi Nasional (2011), the carbon contents of the sub-plots (seedlings, saplings, poles, and trees) were converted to carbon per hectare using the following equation:

$$
C_{n}=\frac{C_{x}}{1,000} \times \frac{10,000}{l_{\text {sub - plot }}}
$$

Where $C_{n}$ is carbon per hectare in each sub-plot $(\mathrm{MgC} / \mathrm{ha}), \mathrm{C}_{\mathrm{x}}$ is carbon per sub-plot $(\mathrm{Kg}) ; 1_{\text {sub-plot }}$ is the area of sub-plot $\left(\mathrm{m}^{2}\right)$.

The biodiversity data were analyzed descriptively. Firstly, the plants and animals were identified by local residents using local names. Then, the photos of animals and herbaria were identified in the laboratory. Secondary data on flora and fauna from PT. Cirebon Electric Power and the Environmental Studies Centre of Universitas Gadjah Mada were also used to identify the species.

\section{RESULTS AND DISCUSSION}

\section{Biodiversity}

In the study site, 15 families and 24 species of plants (Table 2) and 12 species of animals (Figure 2) were recorded. The biodiversity in the Pangarengan mangrove ecosystem was lower than that in the mangrove ecosystem in Bintuni Bay West Papua, one of the largest mangrove ecosystem, that consist of 28 species of true mangrove, 103 species of birds, nine species of reptiles, and seven species of mammals (Yudha et al. 2021). However, this study area has a higher waterbirds diversity than that in the Sabar Miokre mangrove forest, Papua that only five species were recorded (Indrianto et al. 2013). The flora composition in the mangrove forests and riverbanks of the Cipaluh River consisted of trees, bushes, and shrubs. The results were similar to those of Setyawan et al. (2005) and Setyawan and Winarno (2006), where the biodiversity of mangrove areas in Central Java was composed of major, minor, and associated mangrove and habitats consisted of trees, herbs, and bushes.

The Pangarengan mangrove forest was dominated by Rhizophora mucronata, followed by Avicennia marina, Avicennia alba, and Sonneratia caseolaris (Table 3). $R$. mucronata and A. marina in the mangrove forest along Cirebon District coastline were growing naturally and also planted due to the rehabilitation program. A mangrove rehabilitation program that has planted $R$. mucronata was also recorded along the northern Java coastline, such as Karawang (Nusantara et al. 2015), Indramayu (Gunawan et al. 2017), and Pemalang District (Poedjirahajoe et al. 2017).

Table 2. Biodiversity of flora in the Pangarengan mangrove forest

\begin{tabular}{|c|c|}
\hline Family & Species \\
\hline Acanthaceae & $\begin{array}{l}\text { Acanthus ilicifolius } \mathrm{L} . \\
\text { Avicennia alba Blume } \\
\text { Avicennia marina (Forssk.) Vierh. } \\
\text { Ruellia tuberosa } \mathrm{L} .\end{array}$ \\
\hline Aizoaceae & Sesuvium portulacastrum (L.) L. \\
\hline Amaranthaceae & Gomphrena celoisoides Mart. \\
\hline Anacardiaceae & Lannea coromandelica (Houtt.) Merr. \\
\hline Arecaceae & Nypa fructicans Wurmb. \\
\hline Asteraceae & $\begin{array}{l}\text { Chromolaena odorata (L.) R.M. King \& H.Rob. } \\
\text { Cyanthillium cinereum (L.) H.Rob. } \\
\text { Pluchea indica (L.) Less. } \\
\text { Sp.haeranthus indicus L. } \\
\text { Wollastonia biflora (L.) DC. }\end{array}$ \\
\hline Bignoniaceae & Dolichandrone sp.athacea (L.f.) K.Schum. \\
\hline Combretaceae & Terminalia catappa $\mathrm{L}$ \\
\hline Fabaceae & $\begin{array}{l}\text { Derris trifoliata Lour. } \\
\text { Leucaena leucocephala (Lam.) de Wit. } \\
\text { Vachellia leucophloea (Roxb.) Maslin, Seigler \& } \\
\text { Ebinger }\end{array}$ \\
\hline Lamiaceae & Volkameria inermis L. \\
\hline Lythraceae & Sonneratia caseolaris (L.) Engl. \\
\hline Rhizophoraceae & Rhizophora mucronate Poir. \\
\hline Rubiaceae & Morinda citrifolia $\mathrm{L}$ \\
\hline Vitaceae & Causonis trifolia (L.) Mabb. \& J. Wen. \\
\hline
\end{tabular}

Table 1. Equations to estimate biomass

\begin{tabular}{|c|c|c|}
\hline Species & Equation & References \\
\hline Rhizophora mucronata & $\mathrm{DW}=0.251 \rho \mathrm{D}^{2.46}$ & (Komiyama et al. 2005) \\
\hline Avicennia marina & $\mathrm{DW}=0.251 \rho \mathrm{D}^{2.46}$ & (Komiyama et al. 2005) \\
\hline Avicennia Alba & $\mathrm{DW}=0.251 \rho \mathrm{D}^{2.46}$ & (Komiyama et al. 2005) \\
\hline Soneratia sp.p & $\mathrm{DW}=0.258 \mathrm{D}^{2.287}$ & (Kusmana et al. 2018) \\
\hline Nypa fruticans & $\log \mathrm{DW}=0.85 \log \mathrm{D}^{2} \mathrm{~L}+1.54$ & (Matsui et al. 2014) \\
\hline
\end{tabular}

Note: $\mathrm{D}$ is the diameter at breast height (dbh); L is the length of the frond; $\rho$ is the wood density (World Agroforestry 2021) 


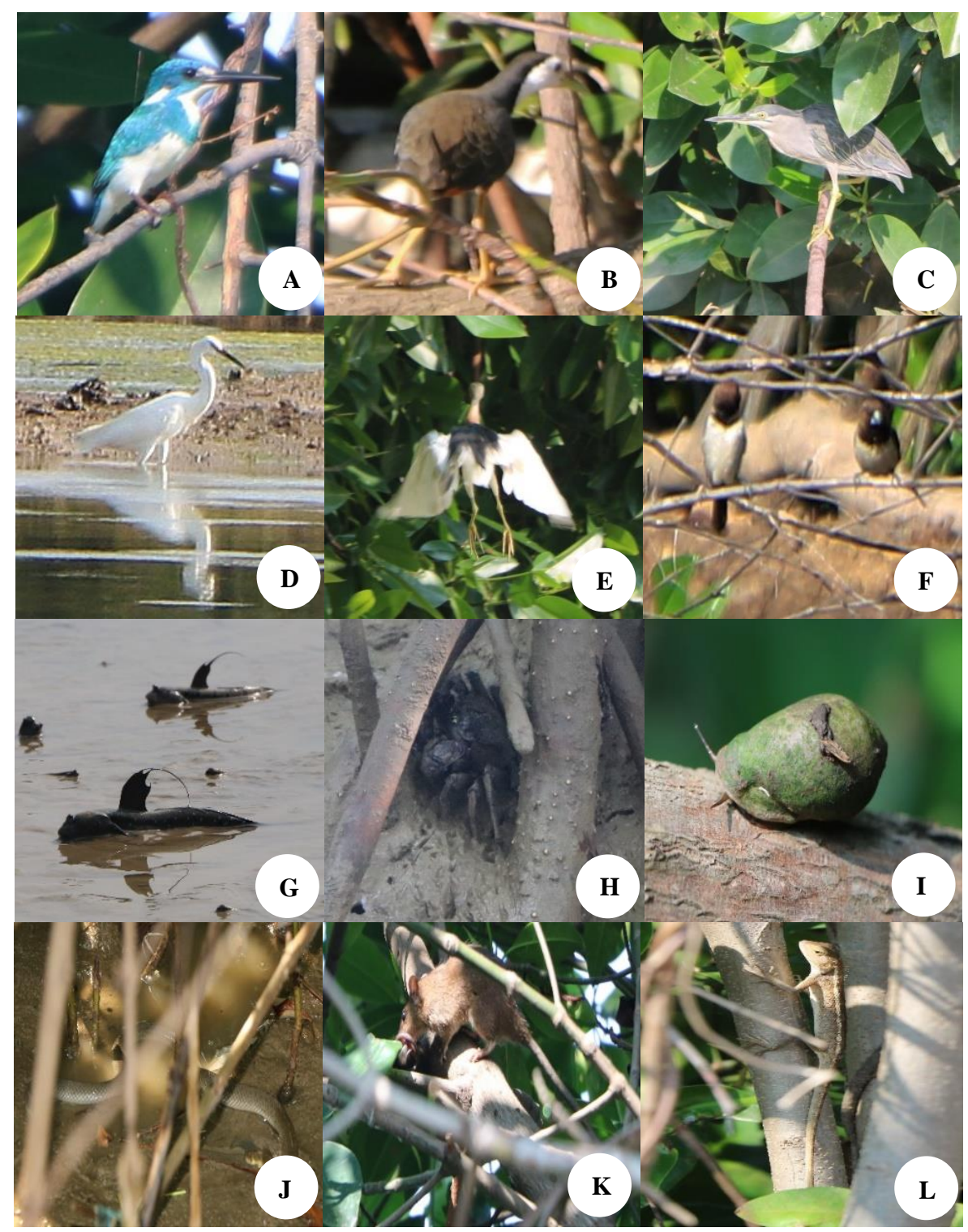

Figure 2. Diversity of fauna in Pangarengan mangrove forest areas: A. Carulean Kingfisher/Raja udang biru (Alcedo coerulescens); B. Gagang Bayam Timur (Himantopus leucocephalus); C. Green-backed heron/Kokokan laut (Butorides striata); D. Little egret/kuntul kecil (Egretta garzetta); E. Javan pond-heron/Blekok sawah (Ardeola speciosa); F. Javan munia/Bondol Jawa (Lonchura leucogastroides); G. Mudskipper (Periopthalamus argentilineatus); H. Crab (Scylla sp.); I. Snail (Phytia sp.); J. Mangrove water snake (Fordonia leucobalia); K. False water rat (Xeromys myoides); L. Oriental garden lizard (Calotes versicolor)

In general, the mangrove vegetation in the northern and southern Java coast is dominated by $R$. mucronata, Sonneratia alba, Nypa fruticans, A. alba, and A. marina (Setyawan et al. 2005). Specifically, along the northern coast of West Java, mangrove forests in the Karangsong, Indramayu District, were dominated by $R$. mucronata, Rhizophora stylosa, Rhizophora apiculata, followed by $A$. marina, A. alba, and S. caseolaris (Gunawan et al. 2017). Meanwhile, in the Karawang District, the mangrove vegetation was dominated by $A$. alba, Bruguiera gymnorrhiza, and $R$. stylosa (Pin et al. 2021). It is evident that the dominant species in the mangrove forest in the western area of the Cirebon District is different from one area to another.
In the east of the Cirebon District, along the northern coast of Central Java, in the Tegal District, $R$. mucronata and A. marina were the dominant species (Isworo and Oetari 2020). Furthermore, in the Pemalang District, the mangrove species composition included $R$. mucronata, $S$. alba, A. alba, R. apiculata, and A. marina (Poedjirahajoe et al. 2017). Meanwhile, in the Rembang District, the dominant mangrove species were Rhizophora and Avicennia (Setyawan and Winarno 2006). In the southern coast of Java, such as Segara Anakan Lagoon in Cilacap District, $R$. mucronata was also the dominant species in the naturally regenerated or in the reforestation areas (Nordhaus et al. 2019). 
Waterbirds dominate the fauna in the Pangarengan mangrove forest. This study has identified six bird species, three reptile species, one mammal species, three malacostraca species, one species of Actinopterygii, and one gastropod. During the research, the presence of birds could be observed more easily than other species. The birds were found on branches, in ponds, or on necromass. According to the research of Hernowo (2016) in Batu Ampar mangrove forest, in West Kalimantan, around $80 \%$ of birds have preferred to use mudflat areas and stratum B (mangrove-trees' crown 5-10 $\mathrm{m}$ above the ground) for their habitat. Meanwhile, the other species are relatively difficult to observe because they are small and live in the mud or soil.

Purnomo et al. (2019) reported 40 species of birds, seven species of reptiles, three species of amphibians, and one mammal species found in the area of PT. Cirebon Electric Power and the coastal area of the Cirebon District. Furthermore, in the Tegal Port, east of the Cirebon District, 37 bird species have been identified (Isworo and Oetari 2020). Commonly, the birds are found in the coastal areas, mangrove areas, and ponds, areas dominated by water birds. The same water birds found in the Cirebon (PT. Cirebon Electric Power and Pengarengan mangrove forest) and the Tegal coastal areas include the little egretta (Egretta garzetta), green-backed heron (Butorides striata), Javan pond-heron (Ardeola speciosa), and Carulean kingfisher (Alcedo coerulescens). The little egretta is also found in the mangrove forests in Thailand (Chanate et al. 2020), Peninsular Malaysia (Mohd-Taib et al. 2020), South Kalimantan Indonesia (Riefani et al. 2019), and West Kalimantan Indonesia (Elfidasari and Junardi 2006).

\section{Carbon stock}

Aboveground carbon stock in the Pangarengan mangrove forest varied among the plot sites. The minimum amount of carbon stock was $11.719 \mathrm{MgC} / \mathrm{ha}$, and the highest was $590.310 \mathrm{MgC} / \mathrm{ha}$. The variation of aboveground carbon stock in the mangrove forest was also recorded by Analuddin et al. (2020) in the National Park of Rawa Aopa Watumohai, Pricillia et al. (2021) in Bali, and Kusumaningtyas et al. (2019) in the Segara Anakan Lagoon, Berau Marine Protected Areas, and Thousand Island, Indonesia. According to Kusumaningtyas et al. (2019), Pricillia et al. (2021), and Analuddin et al. (2020) data, the average of aboveground carbon stock was 969.8 $\mathrm{MgC} / \mathrm{ha}$ in Rawa Aopa Watumohai National Park, Southeast Sulawesi, 68.1 MgC/ha in Nusa Lembongan, Bali, $130.1 \mathrm{MgC} / \mathrm{ha}$ in Berau Marine Protected Areas, East Kalimantan, 74.3 MgC/ha in Thousand Island, Jakarta, and 15.8 MgC/ha in Segara Anakan Lagoon, Central Java.

In the Southeast Asian countries, the amount of aboveground carbon in mangrove forests also varied. For instance, Rozainah et al. (2018) have reported that the mean aboveground carbon in Peninsular Malaysia was 156.35 MgC/ha in Delta Kelantan and 70.17 MgC/ha in Johor Park. Meanwhile, Castillo et al. (2018) reported that the average carbon stock in Honda Bay, Philippines, was
47.9 $\mathrm{MgC} / \mathrm{ha}$. Then, the mean aboveground carbon at Vietnam in the fringe, and the interior forest was 102 $\mathrm{MgC} / \mathrm{ha}, 298.1 \mathrm{MgC} / \mathrm{ha}$, and 243.6 MgC/ha, respectively.

Rhizophora mucronata, found in almost all of the plots, had the highest carbon stock from all species (Table 3). The average carbon stock of $R$. mucronata (seedlings, saplings, poles, and trees) in the Pangarengan mangrove forest was $135.361 \mathrm{MgC} / \mathrm{ha}$. At the other sites, the carbon stock of genus Rhizophora varied. For instance, the aboveground carbon stock of $R$. stylosa at Rawa Aopa Watumohai National Park, Southeast Sulawesi, Indonesia, was $264.50 \mathrm{MgC} / \mathrm{ha}$ (Analuddin et al. 2020). Meanwhile, the $R$. mucronata (saplings and trees) at Segara Anakan in Central Java, Indonesia, were $20.903 \mathrm{MgC} / \mathrm{ha}$ (Widyastuti et al. 2018).

The second dominant species in the Pangarengan mangrove forest was A. marina. The average carbon stock of the A. marina in the Pangarengan mangrove forest was $82.931 \mathrm{MgC} / \mathrm{ha}$. The carbon stock of the A. marina in the Segara Anakan, along the southern coastline of Java, in the mangrove forest was $49.10 \mathrm{MgC} / \mathrm{ha}$ for trees and 79.39 $\mathrm{MgC} /$ ha for saplings (Widyastuti et al. 2018). Other research reported that the carbon in the planted A. marina trees in India was $36.75 \mathrm{MgC} / \mathrm{ha}$ (Kandasamy et al. 2021) and $160.65 \mathrm{MgC} / \mathrm{ha}$ (Kathiresan et al. 2013). Meanwhile, the A. marina on the southern coast of China stored 49.73 $\mathrm{MgC} / \mathrm{ha}$ (Liu et al. 2014).

Table 3. Aboveground carbon stock in the Pangarengan mangrove forest

\begin{tabular}{lcccc}
\hline \multirow{2}{*}{ Species composition } & \multirow{2}{*}{$\begin{array}{c}\text { Total } \\
\text { plots }\end{array}$} & \multicolumn{3}{c}{ Carbon stock (MgC/ha) } \\
\cline { 3 - 5 } & 34 & 11.719 & 381.840 & 135.361 \\
\hline Rhizophora mucronata & 3 & 47.082 & 49.103 & 48.093 \\
Avicennia marina & 2 & & & \\
Rhizophora mucronata & 18 & 31.129 & 590.310 & 160.069 \\
Avicennia marina & & & & \\
$\begin{array}{l}\text { Rhizophora mucronata } \\
\text { Sonneratia caseolaris }\end{array}$ & 6 & 47.060 & 111.587 & 82.931 \\
$\begin{array}{l}\text { Rhizophora mucronata } \\
\text { Avicennia alba }\end{array}$ & 1 & - & - & 157.825 \\
$\begin{array}{l}\text { Rhizophora mucronata } \\
\text { Nypa fructicans }\end{array}$ & 2 & 22.224 & 42.708 & 32.466 \\
$\begin{array}{l}\text { Avicennia marina } \\
\text { Avicennia alba }\end{array}$ & 4 & 26.114 & 117.252 & 65.104 \\
$\begin{array}{l}\text { Rhizophora mucronata } \\
\text { Avicennia marina } \\
\text { Avicennia alba }\end{array}$ & 10 & 30.233 & 491.716 & 171.954 \\
$\begin{array}{l}\text { Rhizophora mucronata } \\
\text { Avicennia alba } \\
\text { Nypa fructicans }\end{array}$ & 1 & - & & \\
\hline
\end{tabular}


Table 4. Average aboveground carbon stock for each species and its life stages

\begin{tabular}{lcccc}
\hline Species & Seedlings & Saplings & Poles & Trees \\
\hline Rhizophora mucronata & 1.084 & 77.708 & 89.815 & 45.280 \\
Avicennia marina & 0.040 & 40.088 & 17.403 & 110.810 \\
Avicennia alba & 0.005 & 2.981 & 12.037 & 71.968 \\
Sonneratia caseolaris & 0.023 & 39.141 & 13.969 & 3.148 \\
\hline
\end{tabular}

Notes: The aboveground carbon stocks are expressed in units of $\mathrm{MgC} / \mathrm{ha}$

Table 3 also showed that the carbon stock in the multispecies plots was higher than in monospecies fields. It can be seen clearly that the highest carbon stock was $590.310 \mathrm{MgC} /$ ha (R. mucronata + A. marina), followed by $491.716 \mathrm{MgC} / \mathrm{ha}$ (R. mucronata + A. marina $+A$. alba $)$, and $461.049 \mathrm{MgC} /$ ha $(R$. mucronata $+A$. alba $+N$. fruticans). Meanwhile, the highest carbon stocks among monospecies were $381 \mathrm{MgC} / \mathrm{ha}$ ( $R$. mucronata). The phenomenon of multispecies carbon stock being higher than monospecies carbon stocks were found in the terrestrial community forest in Java (Wirabuana et al. 2021).

The A. marina tree in the Pangarengan mangrove forest stored the highest amount of carbon, followed by A. alba, $R$. mucronata, and $S$. caseolaris (Table 4). The storage performance of the A. marina was $75 \%$ higher than that of $R$. mucronata on the southern coast of India (Kathiresan et al. 2013). Furthermore, research by Alimbon and Manseguiao (2021) also found that the aboveground carbon stock of $A$. marina was higher than that of $R$. mucronata and $S$. alba.

In conclusion, the Pangarengan mangrove forest has provided environmental services, i.e., conserving biodiversity and storing carbon. A mangrove rehabilitation program needs to be done to increase these environmental services. Future research to document the detailed species composition and structure of mangrove vegetation and the functions of the Pangarengan mangrove forests as ecotourism and as an essential ecosystem are crucial in supporting the mangrove rehabilitation program.

\section{ACKNOWLEDGEMENTS}

PT Cirebon Electric Power, Indonesia funded this research as part of the collaboration between the Directorate of Research Universitas Gadjah Mada, Indonesia and PT. Cirebon Electric Power. We are grateful to the Pangarengan village community for their support during the fieldwork. We also appreciate for the constructive comments from the reviewers. The authors declare that there are no conflicts of interest affecting the publication of this paper.

\section{REFERENCES}

Alimbon JA, Manseguiao MRS. 2020. Species composition, stand characteristics, aboveground biomass, and carbon stock of mangroves in Panabo Mangrove Park, Philippines. Biodiversitas 22 (6): 31303137. DOI: $10.13057 /$ biodiv/d220615.
Analuddin K, Kadidae LO, Haya LOMY, Septiana A, Sahidin I, Syahrir L, Rahim S, Fajar LOA, Nadaoka K 2020. Aboveground biomass, productivity and carbon sequestration in Rhizophora stylosa mangrove forest of Southeast Sulawesi, Indonesia. Biodiversitas 21 (4): 1316-1325. DOI: 10.13057/biodiv/d210407.

Arbiastutie Y, Diba F, Masriani. 2021. Ethnobotanical and ecological studies of medicinal plants in a mangrove forest in mempawah district, Eest Kalimantan, Indonesia. Biodiversitas 22 (6): 3164-3170. DOI: $10.13057 /$ biodiv/d220619.

Badan Standarisasi Nasional. 2011. Standar Nasional Indonesia No. 7724 tentang Pengukuran dan Penghitungan Cadangan Karbon-Pengukuran Lapangan Untuk Penaksiran Cadangan Karbon Hutan (ground based forest carbon accounting). Jakarta. [Indonesian]

Candri DA, Athifah, Farista B, Virgoto A, Rohyani IS, Ahyadi H. 2020. Estimation of carbon stocks in mangrove stands at Bagek Kembar mangrove ecotourism Sekotong West Lombok estimation of carbon stocks in mangrove stands at Bagek Kembar mangrove ecotourism Sekotong West Lombok. IOP Conf Ser: Earth Environ Sci 550: 012013. DOI: 10.1088/1755-1315/550/1/012013.

Castillo JAA, Apan AA, Maraseni TN, Salmo SG. 2018. Tree biomass quantity, carbon stock and canopy correlates in mangrove forest and land uses that replaced mangroves in Honda Bay, Philippines. Reg Stud Mar Sci 24: 174-183. DOI: 10.1016/j.rsma.2018.08.006.

Chanate W, Wasan D, Pisarut Y, Rungtip SA. 2020. The diversity, population, ecology and conservation status of waterbirds in the wetland of Bangpu Nature Education Center, Thailand. Biodiversitas 21 (8): 3910-3918. DOI: 10.13057/biodiv/d210862.

Dinas Kehutanan Provinsi Jawa Barat. 2018. Statistik Kehutanan Jawa Barat Tahun 2017. www.dishut.jabarprov.go.id. [Indonesian]

Eddy S, Iskandar I, Mulyana A. 2017. Land cover changes in the Air Telang protected forest, South Sumatra, Indonesia (1989-2013). Biodiversitas 18 (4): 1538-1545. DOI: 10.13057/biodiv/d180432.

Eddy S, Milantara N, Basyuni M. 2021. Carbon emissions as impact of mangrove degradation: a case study on the air telang protected forest, south sumatra, Indonesia (2000-2020). Biodiversitas 22 (4): 21422149. DOI: $10.13057 /$ biodiv/d220464.

Elfidasari D, Junardi. 2006. Waterbirds diversity in Peniti mangrove forest, Pontianak Regency. Biodiversitas 7 (1): 63-66. DOI: 10.13057/biodiv/d070116

Geldmann J, Barnes M, Coad L, Craigie ID, Hockings M, Burgess ND. 2013. Effectiveness of terrestrial protected areas in reducing habitat loss and population declines. Biol Conserv 161: 230-238. DOI: 10.1016/j.biocon.2013.02.018.

Gunawan H, Sugiarti, Iskandar S. 2017. Dynamics of mangrove community in revegetation area of Karangsong, north coast of Indramayu District, West Java, Indonesia. Biodiversitas 18 (2): 659665. DOI: $10.13057 /$ biodiv/d180230.

Hernowo JB. 2016. Birds communities at mangrove of Batu Ampar, Kubu Raya District, West Kalimantan Province. Jurnal Manajemen Hutan Tropika 22: 138-148. DOI: 10.7226/jtfm.22.2.138. [Indonesian]

Husrin S, Strusińska A, Oumeraci H. 2012. Experimental study on tsunami attenuation by mangrove forest. Earth Planets Space 64 (10): 973-989. DOI: 10.5047/eps.2011.11.008.

Indrianto AP, Budiharjo A, Sugiyarto. 2013. Keanekaragaman jenis burung air di hutan mangrove Sabar Miokre, Pulau Supiori, Papua. Bonorowo Wetl 3 (1): 50-54. DOI: 10.13057/bonorowo/w030105. [Indonesian]

Irawan A, Chikmawati T, Sulistijorini. 2021. Diversity and zonation of mangrove flora in Belitung Island, Indonesia. Biodiversitas 22 (5): 2981-2992. DOI: 10.13057/biodiv/d220563. 
Isworo S, Oetari PS. 2020. Mangrove vegetation and bird communities around Tegal Port, Central Java, Indonesia. Biodiversitas 21 (4): 1551-1560. DOI: 10.13057/biodiv/d210436.

Kandasamy K, Rajendran N, Balakrishnan B, Thiruganasambandam R, Narayanasamy R. 2021. Carbon sequestration and storage in planted mangrove stands of Avicennia marina. Reg Stud Mar Sci 43: 101701. DOI: 10.1016/j.rsma.2021.101701.

Kathiresan K, Anburaj R, Gomathi V, Saravanakumar K. 2012. Carbon sequestration potential of Rhizophora mucronata and Avicennia marina as influenced by age, season, growth and sediment characteristics in southeast coast of India. J Coast Conserv 17 (3): 397-408. DOI: 10.1007/s11852-013-0236-5.

Komiyama A, Poungparn S, Kato S. 2005. Common allometric equations for estimating the tree weight of mangroves. J Trop Ecol 21 (4): 471477. DOI: $10.1017 /$ S0266467405002476.

Kusmana C, Hidayat T, Tiryana T, Rusdiana O. 2018. Allometric models for above- and below-ground biomass of Sonneratia spp. Global Ecol Conserv 15: e00417. DOI: 10.1016/j.gecco.2018.e00417.

Kusumaningtyas MA, Hutahaean AA, Fischer HW, Pérez-mayo M, Ransby D, Jennerjahn TC. 2019. Variability in the organic carbon stocks, sources, and accumulation rates of Indonesian mangrove ecosystems. Estuar Coast Shelf Sci 218: 310-323. DOI: 10.1016/j.ecss.2018.12.007.

Liu H, Ren H, Hui D, Wang W, Liao B, Cao Q. 2014. Carbon stocks and potential carbon storage in the mangrove forests of China. J Environ Manag 133: 86-93. DOI: 10.1016/j.jenvman.2013.11.037.

Matatula J, Afandi AY, Wirabuana PYAP. 2021. Short communication Comparison of stand structure, species diversity and aboveground biomass between natural and planted mangroves in Sikka, East Nusa Tenggara, Indonesia. Biodiversitas 22 (3): 1098-1103. DOI 10.13057/biodiv/d220303

Matsui N, Okimori Y, Takahashi F, Matsumura K, Bamroongrugsa N. 2014. Nipa (Nypa fruticans Wurmb) sap collection in Southern Thailand II. Biomass and Soil Properties. Environ Nat Resour Res 4 (4): 89-100. DOI: 10.5539/enrr.v4n4p89.

Mohd-Taib FS, Mohd-Saleh W, Asyikha R, Mansor MS, AhmadMustapha M, Mustafa-Bakray NA, Mod-Husin S, Md-Shukor A, Amat-Darbis ND, Sulaiman N. 2020. Effects of anthropogenic disturbance on the species assemblages of birds in the back mangrove forests. Wetl Ecol Manag 28 (3): 479-494. DOI: 10.1007/s11273-02009726-z.

Murdiyarso D, Purbopuspito J, Kauffman JB, Warren MW, Sasmito SD, Donato DC, Manuri S, Krisnawati H, Taberima S, Kurnianto S. 2015 The potential of Indonesian mangrove forests for global climate change mitigation. Nat Clim Change 5 (12): 1089-1092. DOI: 10.1038/nclimate2734.

Nordhaus I, Toben M, Fauziyah A. 2019. Impact of deforestation on mangrove tree diversity, biomass and community dynamics in the Segara Anakan lagoon, Java, Indonesia: A ten-year perspective. Estuar Coast Shelf Sci 227: 106300. DOI 10.1016/j.ecss.2019.106300.

Nurmalahayati, Ardli ER, Widyastuti A, Yani E, Piranti AS. 2020. Study of mangrove forest change towards the diversity and carbon stock of mangroves in Segara Anakan, Cilacap. IOP Conf Ser: Earth Environ Sci 550: 012004. DOI: 10.1088/1755-1315/550/1/012004

Nusantara MA, Hutomo M, Purnama H. 2015. Evaluation and planning of mangrove restoration programs in Sedari Village of Kerawang District, West Java: Contribution of PHE-ONWJ coastal development programs. Proc Environ Sci 23: 207-214 DOI 10.1016/j.proenv.2015.01.032.

Onrizal, Mansor M. 2016. Status of coastal forests of the Northern Sumatra in 2005 (after 2004's tsunami catastrophe). Biodiversitas 17 (1): 44-54. DOI: 10.13057/biodiv/d170107.
Pin TG, Supriatna J, Takarina ND, Tambunan RP. 2021. Mangrove diversity and suitability assessments for ecotourism in Cimalaya Wetan Coast, Karawang District, Indonesia. Biodiversitas 22: 803808. DOI: $10.13057 /$ biodiv/d220234.

Poedjirahajoe E, Marsono D, Wardhani FK. 2017. Penggunaan principal component analysis dalam distribusi spasial vegetasi mangrove di Pantai Utara Pemalang. Jurnal Ilmu Kehutanan 11 (1): 29-42. DOI: 10.22146/jik.24885. [Indonesian]

Pricillia CC, Patria MP, Herdiansyah H. 2021. Environmental conditions to support blue carbon storage in mangrove forest: A case study in the mangrove forest, Nusa Lembongan, Bali, Indonesia. Biodiversitas 22 (6): 3304-3314. DOI: 10.13057/biodiv/d220636.

Purnomo S, Taufiqurrahman I, Gunawan. 2019. Keanekaragaman Hayati PT. Cirebon Electric Power edisi Fauna. In: Wibowo E (eds) Yayasan Kanopi Indonesia dan PT. Cirebon Electric Power, Cirebon, West Java. [Indonesian]

Raharjo P, Setiady D, Zallesa S, Putri E. 2016. Identifikasi kerusakan pesisir akibat konversi hutan bakau (mangrove) menjadi lahan tambak di Kawasan Pesisir Kabupaten Cirebon. Jurnal Geologi Kelautan 13 (1): 9-24. DOI: 10.32693/jgk.13.1.2015.258. [Indonesian]

Riefani MK, Soendjoto MA, Munir AM. 2019. Short communication: Bird species in the cement factory complex of Tarjun, South Kalimantan, Indonesia. Biodiversitas 20 (1): 218-225. DOI: 10.13057/biodiv/d200125

Rozainah MZ, Nazri MN, Sofawi AB, Hemati Z, Juliana WA. 2018. Estimation of carbon pool in soil, above and below ground vegetation at different types of mangrove forests in Peninsular Malaysia. Mar Pollut Bull 137: 237-245. DOI: 10.1016/j.marpolbul.2018.10.023.

Sadono R, Soeprijadi D, Susanti A, Matatula J, Pujiono E, Idris F, Wirabuana PYAP. 2020. Local indigenous strategy to rehabilitate and conserve mangrove ecosystem in the southeastern Gulf of Kupang, East Nusa Tenggara, Indonesia. Biodiversitas 21 (3): 1250-1257. DOI: $10.13057 /$ biodiv/d210353.

Setyawan AD, Indrowuryanto, Wiryanto, Winarno K, Susilowati A. 2005. Tumbuhan mangrove di pesisir Jawa Tengah: 1. Keanekaragaman jenis. Biodiversitas 6 (2): 90-94. DOI: 10.13057/biodiv/d060204. [Indonesian]

Setyawan AD, Winarno K. 2006. Permasalahan konservasi ekosistem mangrove di pesisir Kabupaten Rembang, Jawa Tengah. Biodiversitas 7 (2): 159-163. DOI: 10.13057/biodiv/d070214. [Indonesian]

Sihombing VS, Gunawan H, Sawitri R. 2017. Diversity and community structure of fish, plankton and benthos in Karangsong Mangrove Conservation Areas, Indramayu, West Java, Indonesia. Biodiversitas 18 (2): 601-608. DOI: 10.13057/biodiv/d180222.

Widyastuti A, Yani E, Nasution EK, Rochmatino. 2018. Diversity of mangrove vegetation and carbon sink estimation of Segara Anakan Mangrove Forest, Cilacap, Central Java, Indonesia. Biodiversitas 19 (1): 246-252. DOI: 10.13057/biodiv/d190133.

Wirabuana PYAP, Setiahadi R, Sadono R, Lukito M, Martono DS. 2021. The influence of stand density and species diversity into timber production and carbon stock in community forest. Indones J For Res 8 (1): 13-22. DOI: 10.20886/ijfr.2021.8.1.13-22.

World Agroforestry. 2021. Wood Density. http://db.worldagroforestry.org/wd. [30-5-2021]

Yudha RP, Sugito YS, Sillanpää M, Nurvianto S. 2021. Impact of logging on the biodiversity and composition of flora and fauna in the mangrove forests of Bintuni Bay, West Papua, Indonesia. For Ecol Manag 488: 119038. DOI: 10.1016/j.foreco.2021.119038.

Zulhalifah, Syukur A, Santoso D, Karnan. 2021. Species diversity and composition, and above-ground carbon of mangrove vegetation in Jor Bay, East Lombok, Indonesia. Biodiversitas 22 (4): 2066-2071. DOI: 10.13057/biodiv/d220455. 